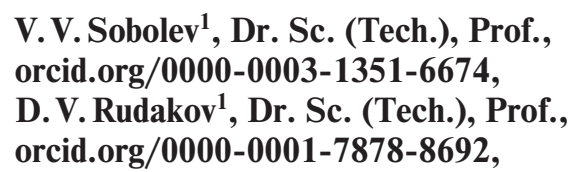

\title{
PHYSICAL AND CHEMICAL TRANSFORMATIONS IN GAS COAL SAMPLES INFLUENCED BY THE WEAK MAGNETIC FIELD
}

Purpose. To study changes in the gas coal sample microstructure, the trends of changing iron concentration and thermal effects of chemical reactions stimulated by the pulsating magnetic field of low intensity.

Methodology. This study used the experimental research methodology, mathematical treatment of the results and analytical methods including X-ray fluorescence spectroscopy, differential thermal and thermogravitational analysis, X-ray diffraction analysis and coal microparticles distribution by fractions, and others.

Findings. Treatment of gas coal samples with weak magnetic and electric fields showed that destructive processes in coal can be initiated both by electric and magnetic fields of weak density. The phase transitions and thermal effects in coal under changing temperature, coal mass changes during heating were defined; temperatures of exothermic and endothermic processes and the enthalpy of new substance formation were evaluated. The microparticle size distribution depending on the treatment method was analyzed.

Originality. It was shown that the iron concentration in recovered gas coal increases with decreasing the grain microparticle size to a limit value corresponding to the iron ash concentration. As a result of the influence of a low intensity pulsating magnetic field strength on the pre-mechanically activated carbon microstructure, the microparticle size increases and, in general, their size range significantly expands. The minimum amount of absorbed heat is required for the chemical compound formation in mechanically activated coal, and the maximum amount is needed for mechanical activation followed by magnetic field treatment that, in the latter case, can be related to additional implementation of spin-selective chemical reactions directly on the coal microparticle surfaces.

Practical value. The obtained experimental results emphasize the fact that weak magnetic fields actively participate in coalification. The results of experimental research can be used in the development of magnetic methods for coal outburst suppression.

Keywords: coal, methane, magnetic field, phase transformations, chemical reactions

Introduction. One of the main problems in coalmining safety is related to methane and coal dust explosions, coal, rock and gas emissions and other gas-dynamic phenomena [1] that are extremely dangerous for workers' lives. The source of permanent threat is methane that is the main component of the coal deposit gas $[2,3]$. Since almost the entire productive coal-bearing strata is saturated with methane, coal deposits are considered as gas-coal (methane-carbon), and methane is widely seen as an independent mineral deposit and an energy and chemical raw material [4]. From this viewpoint, the methane-coal mining provides new solutions for ensuring the safety in operation during the underground extraction of coal deposits and minimizing the possible release of harmful gases into the air; development and application of effective technical solutions and new technologies for the hydrocarbon gas extraction, coal mining, and the use of minerals as chemical and energy raw material. The technical and economic efficiency of the solutions will depend mainly on fundamental scientific results with the completely new ideas about the mechanism of coal formation and physicochemical reactions that occur in coal under the impact to external physical factors. Studies on the fundamental physical characteristics of coal in the case of changing external impacts (pressure, stress conditions, temperature and intensity of weak electric and magnetic fields) have always been on the agenda for the past hundred and fifty years. The solutions for most of these problems are based on

(C) Sobolev V.V., Rudakov D.V., Molchanov O.N., Stefanovych L.I., Kirillov A. K., 2019 the examination of phenomena, regularities, and properties that cause methane and hydrocarbon formation.

Formation of the molecular structure of hard coal, nanoscale carbon and hydrocarbon phases, their thermodynamic stability, occurrence causes and formation mechanisms is the result of various interacting physicochemical effects. The dominating uncertainty in the answers to these questions can be explained by the lack of ideas about basically possible mechanisms of methane formation in coal.

The studies on gas-coal substance properties, occurrence conditions and the pathways of micro- and nanostructural transformations or, more precisely, physical and chemical reactions that can result in the formation of additional quantity of methane, are essential and relevant. In this case, the range of urgent tasks includes solutions to labor protection issues and safety in coal mines. The science dealing with coal and gas emissions has gained rich experience [5], predominantly the results of certain physicochemical reactions that occur in a methane-coal substance. However, such experience does not provide answers to the questions: why the coal and gas or rock and gas emission occurred, why the properties of coal changed, why gas is emitted in an amount that basically cannot be contained in coal, etc.

Methane is known to be the main life hazard to coal miners because it is involved in all gas-dynamic phenomena [6,7] including explosions of methane-air mixtures in underground workings $[8,9]$. Due to this fact, any new knowledge about physical and chemical mechanisms and causes of methane formation in coal will approach solution of important practical 
tasks for mining in the near future. It is, for example, development of the risk management system that will provide a high safety level by creating new technologies for methane-coal mining, which can also offer new solutions to environmental problems caused by the increasing methane content in the Earth's atmosphere, etc.

Studying coal physical characteristics and analyzing possible causes of methane emissions in this paper are carried out using weak physical fields close to those existing in the Earth's crust during tectonic activity [10] in comparison with the data obtained by analyzing the characteristics of outburst-prone coal and coal after the outbursts [11, 12].

The purpose of this study is to analyze changes in the gas coal sample microstructure, the trends of iron concentration changes and thermal effects of chemical reactions stimulated by the pulsating magnetic field of low intensity.

Literature review. Studies on mechanical activation of coal influencing their microstructure by an electric field of low intensity have recently become more extensive [13]. In general, the main feature of such treatment consists in a combination of at least two methods of the sequential impact. The first one (for example, mechanical activation) is intended to increase the reserve of internal energy of the coal microstructure. The second one implies treatment of the microstructure characterized by additional stored energy by weak energy factors, for example, electric and magnetic fields, heating, etc. The idea of using the solid microstructure ability to increase the internal energy reserve is that the second type of impact initiates physical and chemical transformations only in the case of the releasing of excess energy previously stored by the microstructure. Thus, the initiation of physical or chemical reactions occurs when a lower energy barrier is overpassed. In such cases, chemical reactions seem to begin with an obvious lack of external energy to overcome the reaction energy barrier. Since the 1980s, similar treatments of a pre-destabilized microstructure were first used in the studies on the regularities of metastable diamond single crystals growth [14], formation of new phases in ion crystals with electron type of conductivity [15], etc.

Weak magnetic fields were beyond the interest for researchers of phase transition, structural transformation and chemical processes in solids. The main findings in this area are related to the analysis of the living organism behavior under the impact of weak magnetic fields.

Although the coal structure is complex, for assessments it is sufficient to assume a simplified composition containing nanometer-sized crystalline carbon domains that have defects associated with aliphatic amorphous carbon [16]. Coal is characterized by high porosity, and, in general, coal is a multimer consisting of nanocrystals and hydrocarbon and carbon chains. A volume unit of coal may contain up to $30-35$ gas volumes (mainly methane and carbon dioxide).

The discovery of spin-selective chemical reactions in gases and liquids (overcoming the Pauli's ban) in the 1970s [17] became the basis for studies on the possible influence of weak magnetic fields on physical and chemical processes in coal.

The first results of coal microstructure treatment by the weak magnetic field demonstrated [15] the reduction of the combustion heat for untreated coal by $14-15 \%$. This phenomenon can depend on the decrease in hydrogen concentration because 4.2 times more heat is generated during the hydrogen combustion in comparison to carbon combustion. It is assumed that the resulting volatile hydrogen-containing components cause decreasing heat generation during coal combustion. The effect of a magnetic field, like an electric field, stimulates the formation of particles with unpaired electrons (free radicals, ion radicals), thus, increases the paramagnetic centers concentration and the probability of a given product release (thermodynamically stable gas molecules) with the most likely spin-selective and free radical chemical reactions as.

The paper [18] presents the results of studying coal at an early stage of metamorphism by the electrochemical impe- dance method. In contrast to the previous experimental studies $[19,20]$, and quant-mechanical models [21] coal microstructure changes depending on the magnetic field frequency were demonstrated for initial, moistened and dried samples. It was suggested that impact on samples by the pulsating magnetic field of low frequency (in separate frequency ranges) leads to a change in the dielectric permittivity, electric conductivity and coal loss tangent. It was established, for example, that the largest changes in conductivity occur at the frequencies exceeding $104 \mathrm{~Hz}$. Along with this, not all electrophysical characteristics completely return to their initial values after long-term relaxation. The electrophysical parameters changed with alternating behavior during relaxation [18]. Unfortunately, this study did not take into account physical properties of graphenes that may be critical for the coal seam behavior.

The results of studying the changes in the microstructure and properties of moistened gas coal samples after the impact of a pulsating magnetic field with a frequency of $1 \mathrm{~Hz}$ are discussed in other works of T. Vasilenko and co-authors. For the first time, the methods of impedance spectroscopy and a pulse wide line NMR spectrometer at a frequency of hydrogen nuclei ${ }^{1} \mathrm{H}$ allowed interpreting the effect of pulsating magnetic fields on a coal-water system, which can be used in development of the methods of magnetic impact on coal seams in outburst-prone zones.

The studies on chemical and phase composition of coal revealed a sufficiently high iron content with its growth depending on the degree of coal recovery, and the relationship between reductive reactions and coal and gas ejections [12]. Using the Mössbauer spectroscopy for the ${ }^{57} \mathrm{Fe}$ isotope in coals is possible due to enhanced iron content up to $2.7 \%$, sometimes even more. Iron occurs in the form of pyrite $\mathrm{FeS}_{2}$ in coals, oxides, siderite, rosenite, melanterite and mica-like clay minerals (illite). The so-called organically bound iron is found in coal in the form of porphyrins, protein-like structures, iron acetate and iron bound to carboxyl groups.

In order to summarize their own and aforementioned research studies on hydrocarbon formation, the authors of [22] proposed a model of intensive methane generation in coal seams, as well as the initiation of structural destruction with the involvement of $=\mathrm{CH}-$ fragments and $-\mathrm{CH}_{3}-$ groups in the interaction. Testing the hypothesis on the synthesis of saturated aliphatic hydrocarbons in presence of ferrous iron compounds as catalysts is important in the issue of fossil hydrocarbon origins [23]. In the samples of degassed coal with catalysts (ferrous iron compounds) the hydrogen and methane formation was identified with a slight increase in the temperature $\left(50-60{ }^{\circ} \mathrm{C}\right)$. Thus, in a coal seam with a local increase in the temperature the expectation of the Fischer-Tropsch process increases, this was suggested by I. Ryzhenko and I. Yere$\min$ in 1988. They captured a temperature increase in the coal seam outburst area by $15-20{ }^{\circ} \mathrm{C}$.

The authors of studies [24, 25] using the results of coal analysis with the Mössbauer and ${ }^{13} \mathrm{C}$ NMR spectra suggested the appearance of outburst zones with a high methane content in coal depending on the presence of ferrous iron. They assumed additional methane formation during the emission, which is consistent with the main point of the previously proposed hypothesis [26] on the mechanisms of outburst coal formation and evolution of coal and gas emission.

Methods. Recovered gas coal used in experiments was sampled from the $\mathrm{K}_{8}$ seam of the 5/6 Dymytrova coal mine (Myrnohrad city, Donetsk region) and prepared for study as follows. After grinding, the coal was divided into fractions, $\mu \mathrm{m}:<50,63 / 50,80 / 63,100 / 80,125 / 100,160 / 125,200 / 160$, and $250 / 200$. The coal samples were placed in a ceramic cylindrical-shaped container mounted coaxially inside the solenoid. The solenoid was made in a shape of multi-layer winding. The winding length significantly exceeded its diameter that made possible setting up an almost uniform magnetic field in its cavity when an electric current was supplied to the sole- 
noid. The maximum of the magnetic field intensity that could be set up reached about $20,000 \mathrm{~A} / \mathrm{m}$. The methods proposed in $[13,27]$ were used in the experiments. The magnetic field magnitude and the impact time for each coal sample did not exceed $4500 \mathrm{~A} / \mathrm{m}$ and $240 \mathrm{~min}$, respectively. The pulsating magnetic field frequency was $\sim 50 \mathrm{~Hz}$ in all experiments. To conduct a comparative analysis of the results, the coal was treated by an electric field of strength of $250-320 \mathrm{~V} / \mathrm{cm}$ according to the chosen methods $[15,28]$. The coal was treated at a temperature of $45-55{ }^{\circ} \mathrm{C}$, and in only one of the experiments it was equal to the air temperature in the laboratory (about $30^{\circ} \mathrm{C}$ ). When analyzing the obtained results, the results of mathematical modeling [21] and experiments [19, 20] were taken into account. We used X-ray fluorescence spectroscopy (ElvaX spectrometer) and X-ray phase analysis (DRON-3). Moreover, we employed a combined analyzer TG + DSC Netzsch STA 449 F3 Jupiter to evaluate phase transitions and thermal effects in coal depending on temperature changes, coal mass changes during heating, exothermic and endothermic process temperature and the enthalpy of new substance formation. Besides, a laser analyzer of the coal microparticle size was used in the experiments.

Reduced coal is characterized by high iron content [13]. For a proper control of the iron content, samples were prepared from crushed coal. Several samples of various fractions were prepared: from 40 to 250 microns. The element concentration was analyzed using X-ray fluorescence spectroscopy.

The ash content of coal is $A^{d}=10.7 \%$. Burning $1 \mathrm{~kg}$ of coal produces $107 \mathrm{~g}$ of ash that contains $2.85 \%$ of iron, $54 \%$ of quartz and other compounds.
Results. Fig. 1, $a, b$ show the X-ray fluorescence spectra of coal samples with 53/40 and 200/160 fractions. Curve 2 in Fig. 2 shows how iron concentration depends on the fractional composition of analyzed coal samples.

The energy values for the $\mathrm{K} \alpha$ and $\mathrm{K} \beta$-Fe lines are 6.4 and $7.02 \mathrm{keV}$, respectively. The curve on the right within the energy range from 16 to $32 \mathrm{keV}$ reflects the background generated by the device. Analyzing the fat coal spectra, the authors of [29] noted that the smaller the iron contribution is, the bigger the background is. This correlation was observed in analysis of coal from non-outburst areas and after the emission. The similar trend is confirmed in the present work when studying gas coal samples of granularity from 40 to 250 microns. The curve in Fig. 2 reflects the trend indicating an increase in iron concentration with reducing microparticle size. Chemical activity of coal is known to intensify due to the fraction size reduction or the increase in the specific inner surface (L. E. Shterenberg et al., 1968; A. K. Simionscu, 1970; T. M. Khrenkova and M. A. Chubarova, 1973). After magnetic treatment iron concentration increased to $3.72 \%$ from the value of $3.53 \%$ for untreated coal. In comparison, the iron concentration after the exposure to an electric field increased to $4.34 \%$ due to microparticle grinding.

Destructive reactions occur on the phase transition boundary where the part of immovable compounds changes into movable ones such as radicals and gases. One of the main signs of outburst hazard in coal seams is the so-called "overgrinding" (crushing) of coal $[3,5,11]$.

According to the results of radio-frequency, spectroscopy applied to various fractions of coal powder (from $250 \mu \mathrm{m}$ to

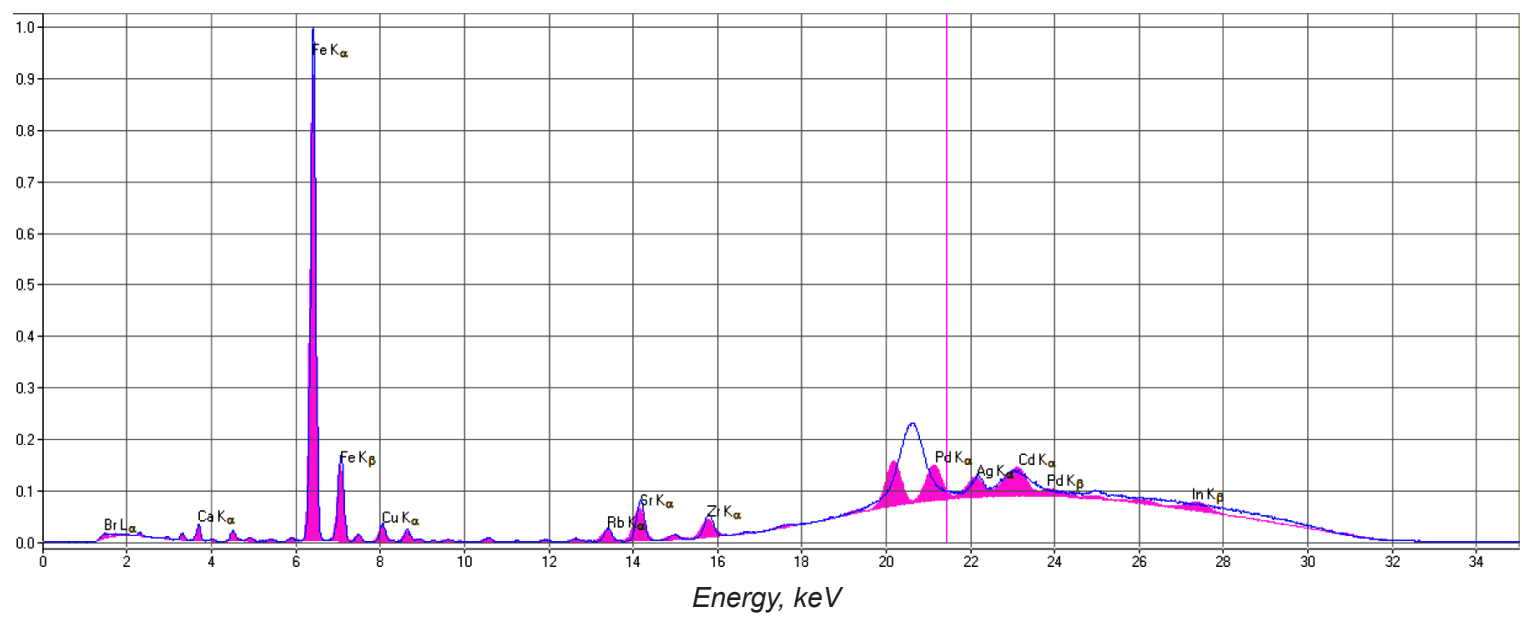

$a$

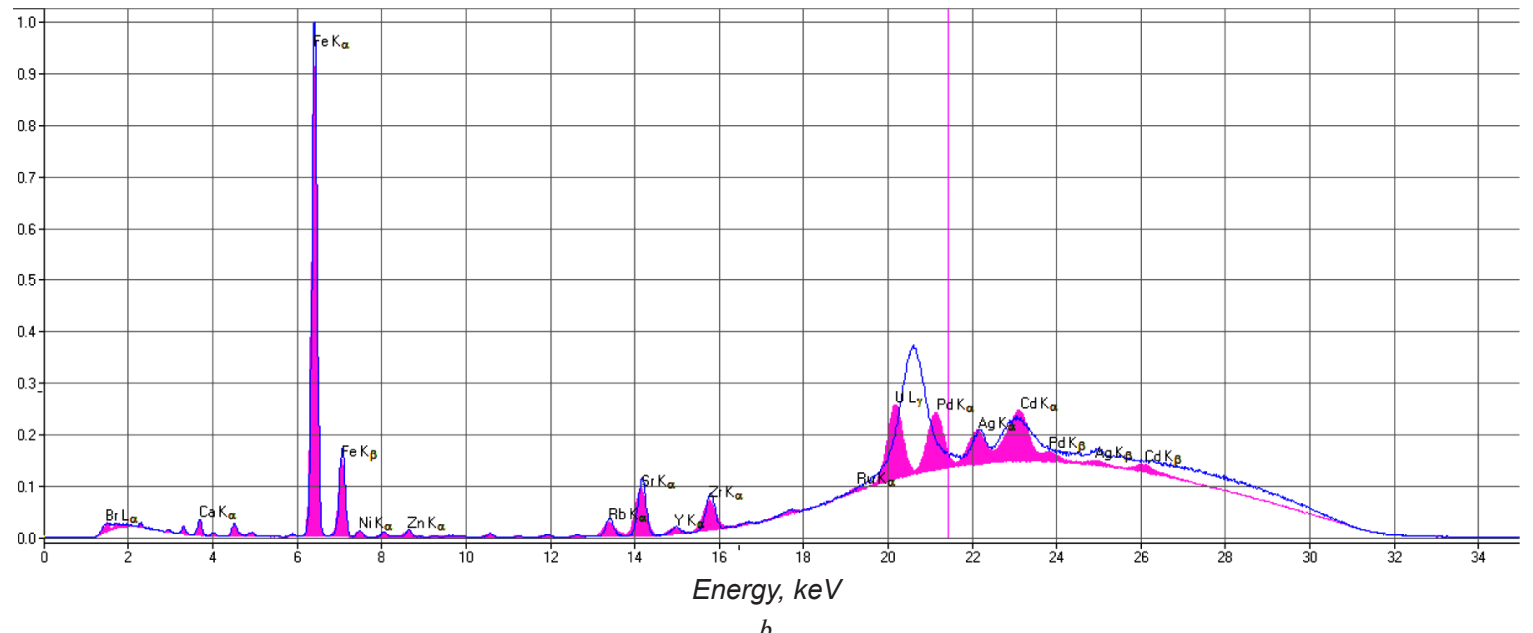

Fig. 1. Coal fluorescence spectra of 53/40 fraction (a) and 200/160 fraction (b) 


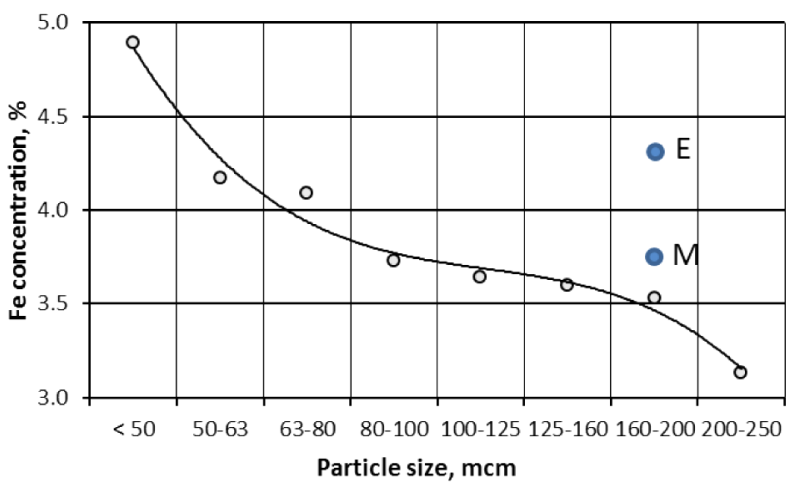

Fig. 2. The iron concentration change in the reduced gas coal from the fractional composition: Points $M$ and $E$ are the coal of 200/160 fraction treated by the magnetic and electric field of low intensity

$<40 \mu \mathrm{m})$, iron concentration increases due to the reduction of the fraction size or an increase in the specific inner surface. In general, an increasing iron concentration with reducing microparticle size can be related to the growing number of exposed inclusions-condensed phases containing iron - on newly formed surfaces. X-ray fluorescence spectra showed that increasing of iron concentration in coal after the emission [29], with reducing coal microparticle size and in coal after treatment by the magnetic and electric field have the same tendency. In this regard, it was assumed that the factors increasing the specific inner surface and the effect of electromagnetic field treatment play a certain role in forming outburst-prone coals.

During magnetic treatment the coal particle size increases and the size range $(184-380 \mu \mathrm{m})$ expands relative to the initial coal $(154-214 \mu \mathrm{m})$ and after electric treatment $(111-184 \mu \mathrm{m})$, i.e. the specific inner surface of the coal sample reduces (Fig. 3). The weak magnetic field impact stimulates chemical reactions leading to stabilizing the unstable equilibrium between the formed radicals and active centers (deformed or strained bonds) located on the particle surfaces of organic coal matter.

Apart from radio-frequency analysis in [24] the Mössbauer spectra of coal samples from non-outburst and outburstprone zones were compared. It was found that the divalent iron signal intensity in the outburst-prone zone exceeds by one order the trivalent iron signal intensity; along with this, the trivalent iron content in all samples is minimal. The trivalent iron is pyrite $\left(\mathrm{FeS}_{2}\right)$ or marcasite that differs from pyrite by the crystal lattice type. The prevalence of divalent iron can be an additional diagnostic sign of outburst-prone coal. In the present study, we found that the coal seam becomes outburstprone when the iron content is at least three times exceeds the

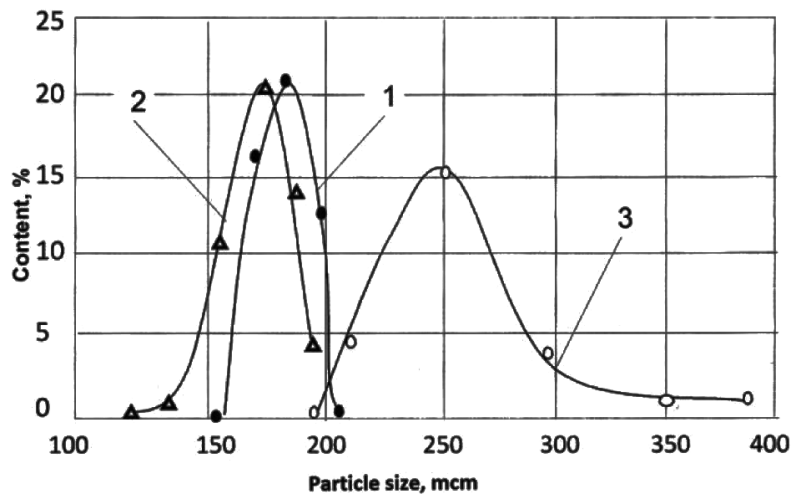

Fig. 3. Distribution pattern of microparticles with 200/160 fraction depending on the method of physical impact on coal:

1 - mechanical activation (initial); 2-mechanical activation and electric field; 3 - mechanical activation and magnetic field background under the prevalence of divalent iron over trivalent iron in total iron content.

In the Earth's crust several different physical factors influence forming minerals and rocks simultaneously. In addition to mechanical and thermal factors, electromagnetic or electrical $[19,20]$ and magnetic $[13,27]$ fields of weak intensities should be also taken into account. An unexpected result of the simultaneous impacts of a weak electric field and heating the samples of dielectric siderite was an abruptly appearing new phase with an electronic type of conductivity in the intergranular boundaries of siderite [15], which was verified by a large number of experiments. The conductive phase in siderite does not appear under separate impacts of heating or an electric field.

In hardcoal studies this previously unknown physical effect is interesting in terms of the mechanism of emerging of electrically conductive phases with an electronic type of bridge wire, in particular, graphene.

Fig. 4 shows the coal diffraction patterns after treatment by weak magnetic and electric fields. Crystalline substances such as quartz were identified by the specific reflection maxima $(\mathrm{d} / \mathrm{n}=4.647 ; 3.659 ; 3.34 ; 2.697 ; 2.449)$, pyrite $(d / n=3.12$; $2.96 ; 2.408 ; 2.21 ; 2.11)$, and others. Ash analysis showed that more than a half of the mass refers to quartz. Diffraction maxima in the range of interplanar distances $d / n=8.56-6.51$ and $d / n=3.8-3.56$ correspond to kaolin, and maxima in the range of interplanar distances $d / n=2.78 ; 1.74 ; 1.498$ and 1.01 refer to siderite; at the same time, siderite was not identified in the original coal sample and after electrical treatment. Comparing the diffraction patterns of Fig. 4 allows identifying the considerable amount of alpha quartz with a maximum line intensity of $0.334 \mathrm{~nm}\left(52.5 \mathrm{imp} / \mathrm{s}\right.$, angle of $\left.31.2^{\circ}\right)$ and the other lines of medium (25-32 imp/s) and weak intensity (10-12 imp/s).

Substantial broadening of a diffraction reflex is typical for substances without long-range bonds. Such X-ray diffraction patterns are specific to liquid and amorphous materials, but in our case they are caused by sample dispersivity. The diffraction pattern contains a broad maximum in the vicinity of the angle $2 \theta \approx 27^{\circ} 40^{\prime}$. The maximum radiation intensity (line $0.334 \mathrm{~nm}$ for $\mathrm{SiO}_{2}$ ) for the untreated sample is $94 \%$, for the sample treated by the magnetic field it raises to $110 \%$ and for the sample treated by the electric field it drops to $42 \%$. Diffraction pattern analysis and comparison of obtained results with the
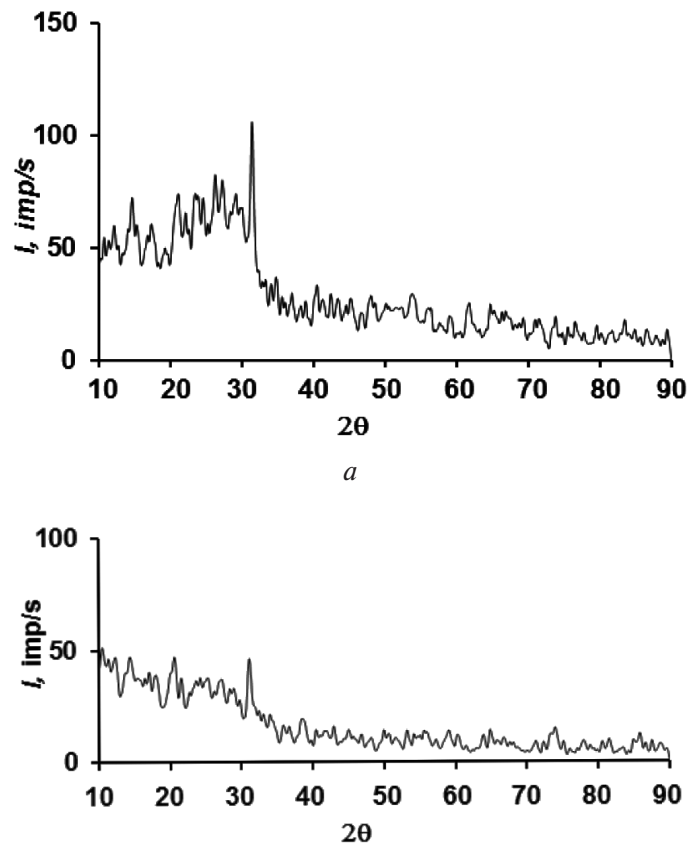

Fig. 4. Diffraction pattern of gas coal with 200/160 fraction after treatment by the electric field (a) and the magnetic field (b) 
results of studying the coal fractional size distribution (Fig. 3) emphasized the microparticle size changes.

In the vicinity of the angle $2 \theta \approx 27^{\circ} 40^{\prime}$ a maximum appears; its half-width reflects the degree of ordering the structure. The smaller the half-width is, the higher order the structure has. The maxima ratio of relative intensities in the vicinity of the angle $2 \theta \approx 27^{\circ} 40^{\prime}$ for the coal treated by the electric field and coal treated by the magnetic field is about $1: 2$. After magnetic treatment, the degree of ordering the coal structure increased significantly compared to the initial structure and the coal treated by the electric field.

Phase transitions and thermal effects in samples with changing coal mass and temperature, the endothermic and exothermic process temperatures and enthalpy were evaluated using thermogravimetry, differential scanning calorimetry and differential thermal analysis using Netzsch STA 449 F3 Jupiter (Fig. 5, Table)

In the experiments, the pulsating magnetic field strength did not exceed $4500 \mathrm{~A} / \mathrm{m}$ and the electric field strength was $250-260 \mathrm{~V} / \mathrm{cm}$. The temperature of the studied coal samples ranged from 320 to $330 \mathrm{~K}$. The air temperature in the laboratory was $24{ }^{\circ} \mathrm{C}$ under the atmospheric pressure. Each sample has been treated for $240 \mathrm{~min}$.

A measure of the isobaric thermal effect or internal energy changes in the studied chemical reactions occurring in coal under atmospheric pressure is an enthalpy conversion that can be negative in case of heat generation or positive when heat is absorbed.
The entropy decrease in experiment 2 in comparison to the coal sample in experiment 1 can be explained by the reserve of additional internal energy in the coal microstructure accumulated during grinding that was released in post-heating of the coal sample.

The largest positive value of enthalpy corresponds to the coal treated by the electric field that leads to the bond destruction of mostly carbon and hydrocarbon chains, and atomic layers on the coal microparticle surface as well as to formation of new molecules. Besides the enthalpy changes, the calorific value decreases for initial not grinded coal by $33554 \mathrm{~kJ} / \mathrm{kg}$, for the sample treated by the magnetic field by $28806 \mathrm{~kJ} / \mathrm{kg}$, and for the sample treated by the electric field by $28480 \mathrm{~kJ} / \mathrm{kg}$. This effect may indicate an increase in the $\mathrm{C}: \mathrm{H}$ ratio, i.e. a significant "loss" of hydrogen deemed to relate to the formation of hydrocarbons including methane, acetylene and other gases at significant quantities or heavy hydrocarbons not contained in untreated coal.

Conclusions. It has been experimentally shown that in the microstructure of pre-mechanically activated (grinded) coal exposed to the weak magnetic field, active physicochemical reactions occur that, in particular, are accompanied by phase transitions, destruction of crystalline and polymer phases, and the formation of new simple and complex compounds.

The main feature of the weak pulsating magnetic field is an increase in the coal microparticle size within any range of fractions. This effect relates to chemical reactions that complete
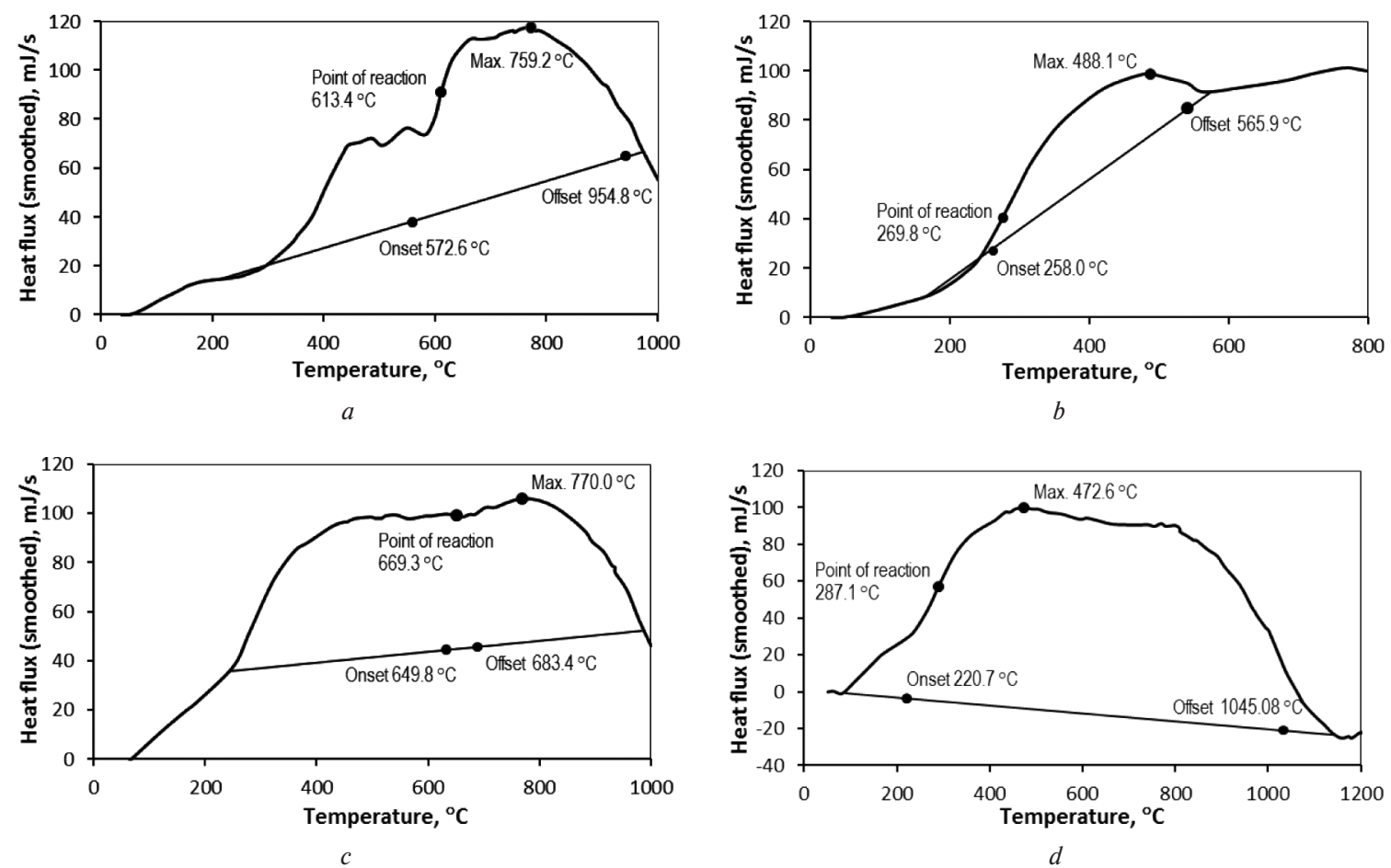

Fig. 5. Results of differential thermal analysis of 200/160 gas coal fraction:

$a$ - untreated coal (pieces); $b$ - mechanically pre-activated grinded coal; $c$ - coal treated by the magnetic field; $d$ - coal treated by the electric field

Key indicators of gas coal differential thermal analysis

\begin{tabular}{|c|c|c|c|c|c|c|c|}
\hline \multirow{2}{*}{ Nr. } & \multirow{2}{*}{$\begin{array}{l}\text { Gas coal sample from } K_{s} \text { seam } \\
\text { (recovered coal) }\end{array}$} & \multicolumn{2}{|c|}{$\begin{array}{l}\text { Chemical reaction } \\
\text { temperature, }{ }^{\circ} \mathrm{C} \\
\end{array}$} & \multirow{2}{*}{$\begin{array}{l}\text { New phase formation } \\
\text { enthalpy, } \mathrm{kJ} / \mathrm{kg}\end{array}$} & \multirow{2}{*}{$\begin{array}{l}\text { Point of } \\
\text { reaction, }{ }^{\circ} \mathrm{C}\end{array}$} & \multirow{2}{*}{$\begin{array}{c}\text { Max. } \\
\text { temperature }{ }^{\circ} \mathrm{C}\end{array}$} & \multirow{2}{*}{$\begin{array}{l}\text { Heat flux, } \\
\mathrm{MJ} / \mathrm{s}\end{array}$} \\
\hline & & Beginning & Ending & & & & \\
\hline 1 & Sample (pieces) & 572.6 & 954.8 & +2484.722 & 613.4 & 759.2 & 117.11 \\
\hline 2 & Initial grinded coal of $200 / 160$ fraction & 258 & 565.9 & +499.1564 & 269.8 & 488.1 & 98.979 \\
\hline 3 & Initial coal treatment by the magnetic field & 649.8 & 683.4 & +3279.787 & 669.3 & 770 & 107.18 \\
\hline 4 & Initial coal treatment by the electric field & 220.7 & 1045.8 & +5777.176 & 287.1 & 472.6 & 100.26 \\
\hline
\end{tabular}


the next atomic layers on the microparticle surfaces. Active growth of coal microparticles in the magnetic field can be the result of catalytic reactions on graphene in relation to the occurrence of cyclotron mass. This process can be interpreted as an effect of magnetic stimulation transiting the metastable system to a stable state with an additional amount of stored energy.

Relaxation in coal after the impacts of magnetic or electric fields is damping over several days and can be well evaluated as a physical parameter that affects the coal microstructure.

Further studies on nonlinear processes initiated by the impact of weak electromagnetic fields on physicochemical transformations in condensed matter with an additional amount of excess internal energy are promising in terms of science and practice.

Scientific interest is due to studying the concept of carbon phase formation, phase transitions of coal organic matter directly into the gas, the influence of graphene properties on the properties of coal overall, etc.

Practical interest is linked with the development of new methods to suppress outbursts in coal and prevent other gasdynamic phenomena, utilization of mine methane and carbon dioxide, the methods for producing new materials from mine gases, etc.

This study was carried out in accordance with the project terms of reference funded by the Ministry of Education and Science of Ukraine. Consulting, ongoing support, and assistance in conducting physical experiments rendered by the colleagues of the State Enterprise Research-Industrial Complex «Pavlohrad Chemical Plant", the Institute for Physics of Mining Processes of the National Academy of Sciences of Ukraine, Dnipro University of Technology, and Ukrainian State University of Chemical Technology are highly acknowledged.

\section{References.}

1. Nikolin, V. I., Zabolotny, A. G., \& Lunev, S. G. (1999). Modern concepts on the nature of outburst hazard and outburst mechanisms as the scientific foundation of labor safety. Donetsk, Publishing house of DonSTU.

2. Shevelev, G. A., \& Lukinov, V. V. (2002). Gas bearing capacity of Donbas rocks. Geotechnical mechanics, 33, 3-7.

3. Bulat, A. F., Skipochka, S. I., \& Palamarchuk, T. A. (2010). Methane generation in coal seams. Monograph. Dnipropetrovsk: Lira Ltd.

4. Verkhovna Rada of Ukraine (2009). On gas (methane) of coal deposits. Law of Ukraine. No. 1392-VI. Retrieved from https://zakon2.rada.gov.ua/laws/show/1392-17.

5. Bolshynsky, M.I., Lysikov, B.A., \& Kapliukhin, A.A. (2003). Gas dynamic phenomena in mines. Monograph Sevastopol: Veber.

6. Zykov, V.S. (2010). Coal and gas outbursts and other gas dynamic phenomena in mines. Kemerovo: "Vostochny" RDC.

7. Bulat, A. F., \& Dyrda, V. I. (2013). Some problems of gas dynamic phenomena in coal mass in terms of nonlinear non-equilibrium thermodynamics. Geotechnical mechanics, 108, 3-31.

8. Griadushchy, B.A., Briukhanov, A. M., Koptikov, V.P., Mkhatvari, T.Ya., \& Timofeyev, E. I. (2013). Causes and effects of gas dynamic phenomena in mines. Coal of Ukraine, (7), 35-41.

9. Sobolev, V. V., Ustimenko, E. B., Nalisko, N. N., \& Kovalenko, I.L. (2018). The macrokinetics parameters of the hydrocarbons combustion in the numerical calculation of accidental explosions in mines. Naukovyi Visnyk Natsionalnoho Hirnychoho Universytetu, (1), 89-98. https://doi.org/10.29202/ nvngu/2018-1/8.

10. Privalov, V.A. (2003). Tectonic nature of Donbas zones of outburst hazard. Coal of Ukraine, (3), 33-37.

11. Frolkov, G. D., Fandeev, M.I., Malova, G. V., \& Frolkov, A. G. (1997). Effect of natural mechanical activation on coal blow-up hazards. Khimiya Tverdogo Topliva, (5), 22-33.

12. Savchuk, V.S., \& Kuzmenko, Ye.A. (2008). Effect of the reduced coals on gas dynamic manifestation in Donbas coal mines. Geotechnical mechanics, 80, 84-90.
13. Pivnyak, G. G., Sobolev, V. V., \& Filippov, A. O. (2012). Phase transformations in bituminous coals under the influence of weak electric and magnetic fields. Naukovyi Visnyk Natsionalnoho Hirnychoho Universytetu, (5), 43-49.

14. Sobolev, V. V., Taran, Yu. N., \& Gubenko, S. I. (1993). Synthesis of diamond in cast iron. Metallovedenie $i$ Termicheskaya Obrabotka Metallov, 1, 2-6.

15. Soboliev, V.V., Bilan, N.V., \& Khalimendik, A. V. (2017). On formation of electrically conductive phases under electrothermal activation of ferruginous carbonate. Naukovyi Visnyk Natsionalnoho Hirnychoho Universytetu, (4), 53-60.

16. Lu, L., Sahajwalla, V., Kong, C., \& Harris, D. (2001). Quantitative $\mathrm{X}$-ray diffraction analysis and its application to various coals. Carbon, 39(12), 1821-1833. https://doi.org/10.1016/ S0008-6223(00)00318-3.

17. Buchachenko, A. L. (2001). Magnetic isotope effect: nuclear spin control of chemical reactions. J. Phys. Chem., A105, 9995. https://doi.org/10.1021/jp011261d.

18. Vasilenko, T.A., Kirillov, A.K., Doroshkevich, A.S., \& Shylo, A. V. (2012). Changes in electrophysical parameters of bituminous coal in terms of magnetic pulse effect. Physical and chemical problems of mining works, 15, 7-19.

19. Molchanov, O., Rudakov, D., Sobolev, V., \& Kamchatnyi, O. (2018). Destabilization of the hard coal microstructure by a weak electric field. E3S Web of Conferences, 60, 00023 (2018). https://doi.org/10.1051/e3sconf/20186000023.

20. Rudakov, D., \& Sobolev, V. (2019). A mathematical model of gas flow during coal outburst initiation. Int. J of Mining Sci. and Tech, 29(5), 791-796. https://doi.org/10.1016/i. ijmst.2019.02.002.

21. Soboliev, V., Bilan, N., Filippov, A., \& Baskevich, A. (2011). Electric stimulation of chemical reactions in coal. Technical and Geoinformational Systems in Mining, 125-130.

22. Shpak, A. P., Alekseiev, A. D., Ulianova, Ye. V., Trachevsky, V. V., \& Chistokletov, V.N. (2012). Nature of methane generation in coal seams. Dopovidi Natsinalnoyi Akademiy Nauk Ukrayiny, 6, 105-110.

23. Glasby, G.P. (2006). Abiogenic origin of hydrocarbons: An historical overview. Res. Geol., 56, 85-98.

24. Ulianova, Ye. V., Razumov, O. N., \& Skoblik, A. P. (2006). Iron and its connection with methane accumulation in coals. Physical and technical problems of mining works, (9), 20-31.

25. Ulianova, Ye. V. (2009). On correlation between ULS and availability of mineral inclusions in coals. Physical and technical problems of mining works, (12), 15-24.

26. Sobolev, V. V. (2003). On the problem of nature of outburst hazard coal formation. Collection of scientific papers of the NMU, 17(1), 374-383.

27. Soboliev, V., Bilan, N., \& Samovik, D. (2013). Magnetic stimulation of transformations in coal. Annual Scientific-Technical Collection. Mining of Mineral Deposits. Leiden: CRC Press/Balkema, 221-225.

28. Soboliev, V., \& Bilan, N. (2015). Electrothermal stimulation of chemical reactions in mixture of calcite and silicon powders. New Developments in Mining Engineering 2015: Theoretical and Practical Solutions of Mineral Resources Mining, 343-348. https://doi.org/10.1201/b19901.

29. Alekseiev, A. D., Ulianova, Ye. V., Vasilkovskii, V.A., Razumov, O. N., Zimina, S. V., \& Skoblik, A. P. (2010). Features of coal structure of outburst hazard zones. Mining research and information bulletin, (8), 165-177.

\section{Фізико-хімічні перетворення у пробах газового вугілля за дії слабкого магнітного поля}

\author{
В. В. Соболєв ${ }^{1}$, Д. В. Рудаков ${ }^{1}$, О. М. Молчанов ${ }^{2}$, \\ Л. I. Стефанович ${ }^{2}$, А. К. Кірілов ${ }^{2}$
}


1 - Національний технічний університет „Дніпровська політехніка“, м. Дніпро, Україна, e-mail: velo1947@ukr.net 2 - Інститут фізики гірничих процесів НАН України, м. Дніпро, Україна

Мета. Вивчити зміни в мікроструктурі зразків газового вугілля, тенденції зміни концентрації заліза та теплових ефектів хімічних реакцій, стимульованих впливом пульсуючого магнітного поля слабкої напруженості.

Методика. Використано методологію експериментальних досліджень, математичну обробку результатів, аналітичні методи: рентгенофлуоресцентний спектральний аналіз, диференційний термічний і термогравітаційний аналізи, рентгеноструктурний аналіз, розподіл мікрочастинок вугілля за фракціям та інше.

Результати. Обробка зразків газового вугілля слабкими магнітними полями довела, що деструктивні процеси у вугіллі можуть бути ініційовані як електричними, так і магнітними полями слабкої напруженості. Визначені фазові переходи й теплові ефекти у вугіллі при зростанні температури; зміни маси вугілля при нагріванні; знайдена температура екзотермічних і ендотермічних процесів, ентальпії утворення нових речовин. Проведено аналіз розподілу мікрочастинок за фракціями в залежності від способу обробки.

Наукова новизна. Показано, що у відновленому газовому вугіллі зі зменшенням зернистості мікрочастинок концентрація заліза зростає до граничного значення, що відповідає концентрації заліза в золі. У результаті впливу пульсуючого магнітного поля слабкої напруженості на мікроструктуру попередньо механоактивованого вугілля збільшуються розміри мікрочастинок і в цілому значно розширюється діапазон їх фракційного складу. Мінімальна кількість тепла, що поглинається потрібна на утворення хімічних сполук у механоактивованому вугіллі, а максимальне значення - у разі механоактивації з подальшою обробкою в магнітному полі, що в останньому випадку може бути пов'язано з додатковою реалізацією спін-селективних хімічних реакцій безпосередньо на поверхнях мікрочастинок вугілля.

Практична значимість. Отримані експериментальні результати вказують на активну участь слабкого магнітного поля у процесах вуглефікації. Результати експериментальних досліджень можуть бути використані при розробці магнітних способів придушення викидонебезпечних станів у вугіллі.

Ключові слова: вугілля, метан, магнітне поле, фазові перетворення, хімічні реакції

\section{Физико-химические превращения в пробах газового угля при действии слабого магнитного поля}

\author{
В. В. Соболев ${ }^{1}$, Д. В. Рудаков ${ }^{1}$, А. Н. Молчанов ${ }^{2}$, \\ Л. И. Стефанович ${ }^{2}$, А. К. Кириллов ${ }^{2}$
}

1 - Национальный технический университет „Днепровская политехника“, г. Днепр, Украина, e-mail: velo1947@ukr.net

2 - Институт физики горных процессов НАН Украины, г. Днепр, Украина

Цель. Изучить изменения в микроструктуре образцов газового угля, тенденции изменения концентрации железа и тепловых эффектов химических реакций, стимулированных влиянием пульсируюшего магнитного поля слабой напряженности.

Методика. Использованы методология экспериментальных исследований, математическая обработка результатов, аналитические методы: рентгено-флуоресцентный спектральный анализ, дифференциальный термический и термогравитационный анализы, рентгеноструктурный анализ, распределение микрочастиц угля по фракциям и др.

Результаты. Обработка образцов газового угля слабыми магнитными и полями доказала, что деструктивные процессы в угле могут быть инициированы как электрическими, так и магнитными полями слабой напряженности. Определены фазовые переходы и тепловые эффекты в угле при росте температуры; изменения массы угля при нагревании; найдена температура экзотермических и эндотермических процессов, энтальпии образования новых веществ. Проведен анализ распределения микрочастиц по фракциям в зависимости от способа обработки.

Научная новизна. Показано, что в восстановленных газовых углях с уменьшением зернистости микрочастиц концентрация железа растёт до предельного значения, соответствующего концентрации железа в золе. В результате воздействия пульсирующего магнитного поля слабой напряженности на микроструктуру предварительно механоактивированного угля увеличиваются размеры микрочастиц и в целом значительно расширяется диапазон их фракционного состава. Минимальное количество поглощаемого тепла требуется на образование химических соединений в механоактивированных углях, а максимальное значение - в случае механоактивации с последующей обработкой в магнитном поле, что в последнем случае может быть связано с дополнительной реализацией спин-селективных химических реакций непосредственно на поверхностях микрочастиц угля.

Практическая значимость. Полученные экспериментальные результаты указывают на активное участие слабого магнитного поля в процессах углефикации. Результаты экспериментальных исследований могут быть использованы при разработке магнитных способов подавления выбросоопасных состояний в углях.

Ключевые слова: уголь, метан, магнитное поле, фазовые превращения, химические реакции

Recommended for publication by I. O. Sadovenko, Doctor of Technical Sciences. The manuscript was submitted 12.02.19. 